\title{
A ÉtiCA MUNDIAL DAS RELIGIÕes E O DESAFIO DO CONFLITO DE CIVILIZAÇÕES
}

\section{Marcello Ciotola ${ }^{1}$}

\section{Resumo}

O artigo aborda a ética mundial das religiões e o desafio do conflito de civilizações. Em um primeiro momento, inserimos o projeto de uma ética mundial comum das religiões, desenvolvido por Hans Küng, no âmbito das éticas de mínimos. Em um segundo momento, sintetizamos o paradigma do conflito de civilizações, apresentado por Samuel Huntington em seu livro O Choque de Civilizações e a Recomposição da Ordem Mundial.

Palavras-chave: Hans Küng; Samuel Huntington; Adela Cortina; ética mundial; choque de civilizações.

\section{INTRODUÇÃO}

No presente artigo sustentamos que a ética mundial comum das religiões, desenvolvida pelo teólogo suíço Hans Küng, nos permite enfrentar o desafio do conflito de civilizações, exposto por Samuel Huntington em sua clássica obra "O Choque de Civilizações e a Recomposição da Ordem Mundial". Na primeira parte do trabalho, priorizando o pensamento de Küng, abordamos os vários caminhos que permitem a construção de uma ética universal de mínimos: o método do construtivismo político (John Rawls), o método da crítica social imanente (Michael Walzer), o método pragmático transcendental da ética do discurso (Karl-Otto Apel e Jürgen

Habermas), o método da ética cívica (Adela Cortina) e o método do Parlamento das Religiões Mundiais (Hans Küng). Na segunda parte, examinamos a tese desenvolvida por Samuel Huntington no sentido de que, no mundo atual, o paradigma da Guerra Fria, marcado pela polarização entre EUA e URSS, foi substituído pelo paradigma do conflito de civilizações, no qual se destaca o confronto entre o Islã e o Ocidente. A metodologia adotada, característica da história das ideias, consiste no estudo de autores.

\footnotetext{
${ }^{1}$ Professor de Filosofia do Direito na Pontifícia Universidade Católica do Rio de Janeiro (PUC -Rio) e na Universidade do Estado do Rio de Janeiro (UERJ). Professor de Ética no programa de pós-graduação em Direito da Universidade Estácio de Sá (UNESA). Doutor em Direito pela PUC-Rio. E-mail: marcellociotola@hotmail.com
} 


\section{A ÉTICA MUNDIAL COMO UMA ÉTICA DE MÍNIMOS}

Adela Cortina observa, em Ética Mínima (prefácio às edições sexta e sétima), que o liberalismo político de John Rawls, o II Parlamento das Religiōes Mundiais (reunido em Chicago no ano de 1993) e o Michael Walzer de Thick and Thin: Moral Argument at Home and Abroad (que descobre, nesta obra publicada em 1994, as possibilidades de alguns mínimos universais) convergem para a ideia de mínimos éticos ou mínimos de justiça(CORTINA, 2001b, p. 20).

Em Los Cristianos en un Estado Laico, Luiz González-Carvajal Santabárbara estabelece uma sinonímia entre ética civil e ética de mínimos, definindo-as como o patrimônio ético compartilhado por todos os grupos humanos que convivem na sociedade. Esta ética comum a todos os cidadãos tem por funções permitir uma convivência pacífica e inspirar a legislação do Estado. De acordo com González-Carvajal, a Declaração Universal dos Direitos Humanos (elaborada por representantes de diversas ideologias e países) e a Declaração em Prol de uma Ética Mundial promovida pelo II Parlamento das Religiões Mundiais (que recolhe princípios e valores éticos presentes em todas as religiões mundiais) podem nos dar uma ideia das dimensões atuais do patrimônio ético comum da humanidade (GONZÁLEZ-CARVAJAL, 2008, p. 45). ${ }^{2}$ Explicitando seu caráter universalizador e integrador, Marciano Vidal assinala que a ética civil, uma espécie de contrafigura da Torre de Babel, busca realizar o antigo desiderato de uma moral comum para toda a humanidade (VIDAL, 2003, p. 669-670).

No entendimento de Adela Cortina e Emilio Martínez Navarro, a articulação de mínimos de justiça e máximos de felicidade nos possibilita (a) construir uma ética cívica democrática, (b) fundamentar, a partir dos mínimos de justiça, as éticas aplicadas (bioética, ética da economia, ética da empresa, ética ecológica, etc.) e (c) construir uma ética universal com base nas exigências mínimas de justiça, dentre as quais se inclui o dever de respeitar os diferentes modelos de felicidade dos grupos e culturas (CORTINA e MARTÍNEZ, 2005, p. 115116).

Nas palavras de Adela Cortina, as éticas de máximos ou éticas da felicidade - que em uma sociedade verdadeiramente moderna são plurais - são as concepções de mundo (sejam elas religiosas, agnósticas ou ateias) que propõem um modelo de vida feliz e se pronunciam acerca do sentido da vida e da morte. Contrariamente, a ética de mínimos ou ética da justiça não propõe um modelo de vida feliz, assim como não se pronuncia sobre o sentido da vida e da morte, restringindo-se às questões de justiça, que são aquelas moralmente exigíveis a todos os cidadãos (CORTINA, 1998, p. 117; 2003b, p. 38). Para a professora da Universidad de Valencia, o pluralismo moral, que supera o movimento pendular entre monismo moral (código moral único) e politeísmo moral (Babel moral), consiste em compartilhar alguns mínimos de justiça e, ao mesmo tempo, respeitar ativamente os máximos de felicidade e de sentido da vida (CORTINA, 1998, p. 113 e 117). 
Conforme assinala Adela Cortina, a articulação entre a ética pública cívica comum de mínimos e as variadas éticas públicas de máximos ou, se preferirmos, a articulação entre mínimos e máximos, deve obedecer a quatro diretrizes. Primeiramente, a ética cívica e as éticas de máximos devem manter uma relação mútua de não absorção, o que significa dizer que, por um lado, a ética civil não tem legitimidade para tentar anular as éticas de máximos que respeitam os mínimos de justiça e, por outro, as éticas de máximos não têm legitimidade para anular a ética civil. Em segundo lugar, os mínimos se alimentam dos máximos; estes últimos são o solo nutritivo dos primeiros: quem formula exigências de justiça o faz com base em um projeto de felicidade. Em terceiro lugar, as éticas de máximos podem ser purificadas a partir das exigências da ética mínima. Por fim, a ética cívica comum e as éticas de máximos não devem se distanciar. Os mínimos compartilhados devem ser explicitados, é claro, mas não como se constituíssem um mundo separado das diversas propostas de felicidade. Tanto uma ética civil autossuficiente, alheia às éticas de máximos, como uma ética de máximos autossuficiente, alheia à ética civil, são inadmissíveis (CORTINA, 1998, p. 120-122; 2001b, p. 19). Para Adela Cortina e Emilio Martínez:

As éticas da justiça ou éticas de mínimos ocupam-se unicamente da dimensão universalizável do fenômeno moral, isto é, daqueles deveres de justiça que são exigíveis de qualquer ser racional e que, em suma, só compõem algumas exigências mínimas. As éticas da felicidade, ao contrário, tentam oferecer ideais de vida boa (...). São, portanto, éticas de máximos, que aconselham a seguir um modelo, nos convidam a tomá-lo como orientação da conduta, mas não podem exigir que seja seguido, porque a felicidade é objeto de conselho e de convite, não de exigência (CORTINA e MARTÍNEZ, 2005, p. 115).

Os conceitos de (a) ética de mínimos (ética mínima) e de (b) éticas de máximos, desenvolvidos por Adela Cortina, correspondem, respectivamente, aos conceitos rawlsianos de (a) concepção moral da justiça para a estrutura básica da sociedade e de (b) doutrinas compreensivas do bem (CORTINA, 1998, p. 117). ${ }^{3}$ De acordo com John Rawls, uma doutrina abrangente ou compreensiva (seja ela religiosa, filosófica ou moral) pretende englobar todos os aspectos da vida humana, ou seja, amplia seu âmbito para além do político, de modo a incluir valores e virtudes não-políticos. Por sua vez, a concepção política de justiça, que é uma concepção moral alicerçada em um consenso sobreposto razoável, é um ponto de vista comum, a partir do qual cidadãos que possuem opiniões religiosas, filosóficas e morais conflitantes podem solucionar questões relativas aos elementos constitucionais essenciais (RAWLS, 2000b, p. 53 e 222; 1999, p. 617; 2003, p.45). Rawls assinala que o dualismo existente, no liberalismo político, entre o ponto de vista da concepção política e os diversos pontos de vista das doutrinas abrangentes ou compreensivas decorre da própria natureza particular da cultura política democrática, marcada pelo pluralismo razoável. Portanto, explicita Rawls, em uma sociedade democrática unificada por princípios de justiça, os cidadãos sustentam dois pontos de vista diferentes, apesar de intimamente relacionados: a concepção política de justiça que todos endossam e uma dentre as várias doutrinas compreensivas existentes na

\footnotetext{
${ }^{2}$ Para Cortina, a moral cívica é, por essência, uma moral mínima (CORTINA, 2001a, p.196).

${ }^{3}$ Em que pesem as grandes semelhanças existentes entre a ética cívica e o que Rawls chama de concepção moral da justiça, para um exame das diferenças entre ambas, ver CORTINA, 2003a, p. 285-286.
} 
sociedade (RAWLS, 2003, p. 45-46; 2000b, p. 29).

Em sua História da Filosofia Moral, Rawls nos lembra que a Reforma protestante de 1517 deu origem aos conflitos das guerras religiosas, suscitando um problema novo, consistente em saber como é possível conviver com pessoas que professam uma religião impositiva e salvacionista diferente (RAWLS, 2005, p. 10-11). Nesta linha de pensamento, Adela Cortina enfatiza que a ética cívica é uma ética da modernidade, que surge (nos séculos XVI e XVII) a partir da constatação de que a convivência entre cidadãos que defendem diferentes cosmovisões (religiosas, agnósticas ou ateias) é possível, desde que eles compartilhem um mínimo de valores e normas, ou seja, o compartilhamento de alguns mínimos é o que possibilita a convivência dos máximos (CORTINA, 2003b, p. 37; 2001a, p. 196). ${ }^{4}$ Se a Reforma, com suas consequências, está na origem histórica do liberalismo político e do liberalismo em geral, escreve Rawls, o problema do liberalismo político, que é um problema de justiça política e não um problema acerca do bem supremo, consiste em saber como é possível a convivência, ao longo do tempo, de cidadãos livres e iguais que se encontram profundamente divididos por doutrinas religiosas, filosóficas e morais razoáveis. Após explicitar que o pluralismo razoável (que não é algo desastroso, mas sim o resultado das atividades da razão humana em um contexto de instituições livres e duradouras) é um pluralismo de doutrinas abrangentes, tanto religiosas como não-religiosas, John Rawls nos ensina que:

o sucesso do constitucionalismo liberal manifestou-se como a descoberta de uma nova possibilidade social: a possibilidade de uma sociedade pluralista estável e razoavelmente harmoniosa. Antes da prática pacífica e bem-sucedida da tolerância em sociedades com instituições liberais, não havia como saber da existência dessa possibilidade. É mais natural acreditar, como a prática da intolerância ao longo de séculos parece confirmar, que a unidade e a paz social requerem concordância em relação a uma doutrina religiosa geral e abrangente, ou a uma doutrina filosófica ou moral. A intolerância era aceita como uma condição da ordem e estabilidade sociais. $\mathrm{O}$ enfraquecimento dessa idéia ajuda a preparar o terreno para as instituições liberais. Talvez a doutrina da liberdade religiosa se tenha desenvolvido porque é difícil, senão impossível, acreditar na danação daqueles com os quais, confiantes, cooperamos longa e frutiferamente na manutenção de uma sociedade justa (RAWLS, 2000b, p. 32).

Rawls afirma, em Justice as Fairness: Political not Metaphysical, que a concepção pública da justiça deve ser política, e não metafísica (abrangente), o que significa dizer que não deve depender de doutrinas religiosas e filosóficas sujeitas a controvérsias (RAWLS, 2000a, p. 202). Como esclarece Catherine Audard, a concepção política de justiça, com seu caráter ecumênico e consensual, em nada compromete as filiações filosóficas e religiosas de cada um. Objeto de um consenso sobreposto (overlapping consensus) de doutrinas abrangentes e razoáveis, denomina-se "política" pelo fato de que pode ser aceita por todos os cidadãos ou membros da pólis (AUDARD, 2000, p. XVI). De forma similar, a ética cívica, nos termos de Adela Cortina, é a ética dos indivíduos enquanto cidadãos ou membros de uma pólis (CORTINA, 1998, p. 115).

${ }^{4}$ Para um resumo das características da ética cívica, ver CIOTOLA, 2014, p. 156-159. 
Partindo do pressuposto de que toda moral é pública (não existem morais privadas, pois toda moral tem vocação para se apresentar em público), Adela Cortina diferencia ética pública cívica de ética pública global ou universal. A ética pública cívica é a ética dos cidadãos de uma comunidade política concreta, a ética dos cidadãos de uma sociedade moralmente pluralista. Trata-se de uma ética cívica nacional. Por sua vez, a ética pública global ou universal, entendida como uma ética intercultural não etnocêntrica, é a ética dos cidadãos do mundo. Trata-se de uma ética cívica transnacional (CORTINA, 1998, p. 109-110; 2010, p. 144). Tendo em mente a famosa passagem de "O a priori da comunidade de comunicação e os fundamentos da ética", na qual Karl-Otto Apel, na primeira metade da década de 1970, aponta o paradoxo segundo o qual a fundamentação racional de uma ética universal da responsabilidade solidária nunca foi tão difícil e ao mesmo tempo tão necessária, a professora da Universidad de Valencia assinala que:

No começo do terceiro milênio, muitas vozes se levantam, lembrando que é necessário esboçar uma ética universal. Diante da globalização econômica e informática, diante das conseqüências universais das tecnologias, torna-se cada vez mais evidente a necessidade de uma ética planetária, que oriente moralmente o processo de globalização a partir dos valores éticos universais ou a partir de uma razão prática universal. Se for preciso orientar a globalização de outra maneira, se for preciso orientá-la a partir de uma perspectiva ética distinta, essa perspectiva não pode ser própria de um só grupo, nem sequer de um conjunto de grupos, mas precisa ser universal, para conseguir que todos os seres humanos se beneficiem das suas vantagens e para evitar que o abismo entre pobres e ricos continue se alargando (CORTINA, 2003a, p. 274). ${ }^{5}$

Adela Cortina enumera duas dificuldades para a construção de uma ética global ou universal (apta a encontrar respostas éticas comuns para determinados problemas que afetam toda a humanidade): em primeiro lugar, o relativismo e o pragmatismo contextualista se fazem presentes não apenas em boa parte dos textos de filosofia moral e política como também na moral e na política cotidianas; em segundo lugar, diante da inegável realidade do multiculturalismo (tanto no âmbito das sociedades concretas como no âmbito mundial), surge o complexo problema de conciliar a diversidade cultural com a necessidade urgente de uma ética universal (CORTINA, 2003a, p. 276-278; 2005, p. 145-146).

De acordo com Adela Cortina, apesar das dificuldades apontadas, existem vários métodos ou caminhos filosóficos para construir uma ética global da responsabilidade com força normativa (CORTINA, 2005, p. 146 e segs; 2003a, p. 278 e segs.; 2010,p. 143-144; 1998, p. 110).O método do construtivismo político rawlsiano parte das exigências de justiça da cultura ocidental e as estende para as demais culturas. Em The Law of Peoples, escreve Adela Cortina, Rawls aplica ao âmbito internacional o procedimento de contornar as diferenças existentes entre as doutrinas compreensivas do bem e constrói, assim, uma concepção moral da justiça (compreendida como uma certa ética universal) extensível a países não liberais. O método da crítica social imanente, que encontramos no segundo Michael Walzer, pretende construir uma ética global a partir dos valores e princípios éticos efetivamente

\footnotetext{
${ }_{5}^{5}$ Para a mencionada passagem de Karl-Otto Apel, ver APEL, 2000, p. 407.
} 
compartilhados pelas diferentes culturas. O objetivo de Walzer em Thick and Thin consiste em endossar a política da diferença e, ao mesmo tempo, descrever e defender certa forma de universalismo. Para isso, nas palavras de Adela Cortina, Michael Walzer estabelece uma diferença entre moralidades densas particularistas (thick moralities) e moralidade tênue universalista (thin morality): as primeiras se manifestam em cada sociedade particular, ao passo que a segunda (a rigor, um conjunto de mandados negativos que proíbem o genocídio, a escravidão e o tratamento cruel) pode ser estendida a todas as sociedades, em ocasiões críticas. O método pragmático transcendental da ética do discurso reconhece, a partir do fato inegável da argumentação, o caráter dialógico da razão e, na medida em que pretende ser axiologicamente neutro, limita-se a estabelecer os procedimentos racionais para a justificação de normas. Adela Cortina, por sua vez, propõe um quarto método, objetivando fundamentar a obrigação de uma ética universal. O novo caminho, além de conservar o que há de melhor nos anteriores, atenta para aquilo que historicamente está ocorrendo. Estamos diante de uma ética cívica transnacional, capaz de fundamentar uma cidadania cosmopolita. Esta ética dos cidadãos do mundo (ética pública global ou universal) deve ser uma ética intercultural, não etnocêntrica, construída a partir do diálogo entre as distintas culturas. Para Cortina, pode-se perceber ainda que, não somente uma ética cívica comum, cada vez mais, aproxima os diversos países, como também que o aparecimento e a evolução da ética cívica se dá no âmbito de uma referência transnacional. Elucidando sua proposta, a professora da Universidad de Valencia assinala:

À diferença do Liberalismo Político, que parte da concepção moral da justiça dos Estados Unidos e, depois, tenta "adelgaçá-la" para estendê-la aos países não democráticos, partiremos aqui do fato da existência da ética cívica em sociedades situadas no nível pós-convencional no desenvolvimento da consciência moral, documentaremos que essa ética cívica já é transnacional, porque na sua configuração colaboram os diversos países que a compartilham, e também que paulatinamente ela vai se estendendo, de modo que o acordo transnacional é cada vez maior. A ética ć́vica nasceu nas sociedades pluralistas em que um certo republicanismo moral acaba sendo imprescindível, mas, por sua própria natureza, é transnacional e é praticada transnacionalmente. Para fundamentá-la racionalmente é preciso recorrer a uma Hermenêutica Crítica Transcendental, que permite reconstruir as suas pressuposições. Essa hermenêutica é semelhante a que propõe Karl-Otto Apel, mas difere um tanto dela (CORTINA, 2003a, p. 278).

No último capítulo de Justicia Cordial, ao examinar os possíveis caminhos em direção a uma ética global, Adela Cortina aproxima os métodos utilizados pelo Parlamento das Religiões Mundiais e por Michael Walzer (em Thick and Thin), compreendendo ambos como direcionados a descobrir os valores e princípios éticos compartilhados pelas diferentes culturas para, a partir deles, construir uma ética mundial de justiça (CORTINA, 2010, p. 143-144).Parece-nos, no entanto, que os métodos do segundo Walzer e do Parlamento das Religiões Mundiais não chegam exatamente a se confundir. Desse modo, partindo do valioso esforço de sistematização empreendido por Adela Cortina, tenderíamos a considerar, auxiliados por Juliana Ludmer e pelo próprio Hans Küng, que o Parlamento das Religiões Mundiais nos oferece, a rigor, um quinto método para construir uma ética universal. 
O método walzeriano da crítica social imanente, na precisa síntese feita por Adela Cortina, consiste em penetrar nas moralidades densas, que se manifestam em cada sociedade particular, para, a partir delas, descobrir a moralidade tênue que marca o limite do tolerável. Contudo, esta moralidade tênue universalista, a não ser diante das injustiças mais brutais e ofensivas, não nos permite crịticar outras moralidades densas diferentes da nossa (daí a ideia de que a crítica social deve ser imanente) (CORTINA, 2003a, p. 280-281).

Hans Küng identifica-se, pelo menos a princípio, com a abordagem concreta que leva Michael Walzer a reconhecer a existência de valores universais como "verdade" e "justiça" (KÜNG, 2014, p. 483; 1999, p. 170172).O teólogo suíço, inclusive, compartilha da desconfiança walzeriana em relação aos filósofos que (a exemplo de Rawls, Apel e Habermas) procedem de uma maneira racional e abstrata; conforme seu entendimento, não parece razoável ignorar as religiões e as culturas a fim de, com base num discurso racional e abstrato, impor um ethos global vinculante capaz de atingir a mais remota aldeia africana ou indiana (KÜNG, 1999, p. 173-174). Contudo, Hans Küng sugere que, ao invés de falarmos em moral tênue (fina) e moral densa (grossa), utilizemos, respectivamente, os termos moral elementar e moral culturalmente diferenciada. Em relação à primeira, restrita a um pequeno número de exigências fundamentais, um consenso global é perfeitamente possível; no que concerne à segunda, que abrange numerosos elementos culturais específicos, o consenso não se faz necessário. Para Hans Küng:

No caso local ou regional concreto, moral "fina" e "grossa" (...) encontram-se misturadas. Não obstante isto, a distinção é importante. Que, por exemplo, não seja permitido torturar crianças faz parte, nas diferentes culturas, da moral pura (moral "fina"), que tem validade tanto em São Francisco como em Cingapura. Mas quando, para uma criança, um castigo corporal passa a ser considerado como tortura, isto, manifestamente, é julgado em São Francisco de uma maneira diferente do que em Cingapura, e aqui entram em consideração muitos fatores históricos, culturais, políticos e religiosos. E não passaria de imperialismo cultural se quiséssemos introduzir os costumes específicos de São Francisco em Cingapura ou os de Cingapura em São Francisco (KÜNG, 1999, p. 175).

Em última instância, entretanto, embora reconheça o esforço de Michael Walzer para descrever e defender um ethos comum da humanidade, Hans Küng afirma que há um caminho mais convincente para apresentar de maneira mais substancial aquilo que o filósofo norte-americano chama de mínimo moral. Se para Walzer existe um dualismo entre moralidade mínima e moralidade máxima, para Hans Küng, diferentemente, entre ambas existe uma continuidade. Além disso, o teólogo suíço sustenta que o conteúdo do consenso ético básico pode ser determinado de forma mais detalhada, indo além de palavras programáticas e genéricas, como verdade e justiça. Uma concretização do ethos mundial, em suma, não pode pretender oferecer nem um máximo denso nem apenas um mínimo tênue de consciência ética (KÜNG, 1999, p. 175-177 e 188-190). ${ }^{6}$

\footnotetext{
${ }^{6}$ Para um aprofundamento dos conceitos walzerianos de maximalismo moral e minimalismo moral, ver CIOTOLA, 2013, p. $207-$ 218.
} vol.09, nº. 04, Rio de Janeiro, 2016.pp. 2248-2262 
No segundo capítulo de O Projeto de Ética Mundial de Hans Küng, Juliana Ludmer explicita que, no entendimento do teólogo suíço, a justiça como imparcialidade rawlsiana, a ética do discurso, o direito natural e mesmo a moral tênue de Michael Walzer, não são suficientes para embasar uma consciência ética global. Com sofisticação e rigor acadêmicos, Juliana Ludmer percebe que a proposta de ética mundial de Hans Küng apresenta um caráter prescritivo ou normativo, ao passo que o minimalismo moral de Walzer apresenta um caráter meramente descritivo, limitando-se a descrever princípios e regras reiteradas pelas diferentes culturas (LUDMER, 2016, p. 62-70). Surge assim a questão de saber como é possível formular uma ética prescritiva para toda a humanidade. Em suas memórias, Hans Küng escreve:

Yo (...) defiendo que es posible constatar empíricamente normas concretas y universales o universalizables que, si bien no se centran exclusivamente en la razón, son racionales. Así pues (...) quiero recurrir a las tradiciones de las civilizaciones y religiones y, desde ellas, aprovechar la posibilidad de diálogo entre las diferentes civilizaciones y religiones (KÜNG, 2014, p. 483).

No terceiro capítulo de O Projeto de Ética Mundial de Hans Küng, Juliana Ludmer (LUDMER, 2016, p. 70) acentua que o diálogo intercultural amplo é o método sugerido por Küng para definir o conteúdo do ethos mundial. Mais adiante, no quarto capítulo, a autora, apoiada em terminologia de José Rubio Carracedo, nos ensina que o projeto de ética mundial elaborado pelo teólogo suíço pode ser classificado como metodológico construtivista, uma vez que estamos diante de princípios éticos universais mínimos construídos a partir de um amplo e constante diálogo intercultural (LUDMER, 2016, p. 97). A ética prescritiva universal, em suma, deve ser forjada por intermédio de um diálogo intercultural.

Diante de um primeiro grupo de filósofos (como Alasdair Maclntyre, Richard Rorty, Michel Foucault e Rüdiger Bubner) que pensam que, como só há éticas regionais, não é possível estabelecer um consenso básico global em questões de consciência ética, e de um segundo grupo de filósofos (como, por exemplo, Jean-François Lyotard e Wolfgang Welsch) que, a partir de um pluralismo radical pós-moderno, preferem falar em "verdade, justiça e humanitarismo” no plural, Hans Küng defende a existência de padrões éticos universalmente válidos (KÜNG, 1999, p. 168-169). Partindo da premissa de que um consenso ético básico (portanto, um consenso ético mínimo e não um consenso ético total) é indispensável para a sociedade mundial, Küng define o ethos mundial ou global como o mínimo de valores, normas e atitudes que devem ser comuns a todos os homens (KÜNG, 1999, p. 166, 168 e 170).Evocando Ralf Dahrendorf (o que mantém a sociedade moderna coesa?) e ErnstWolfgang Böckenförde (será que o Estado liberal secularizado se alimenta de pressupostos normativos que ele próprio não é capaz de garantir?), aos quais acrescentaríamos John Rawls e o já mencionado problema do liberalismo político, Hans Küng nos oferece a seguinte resposta para a questão de saber o que manterá, em um contexto de emancipação e secularização, a sociedade coesa: 
Certamente não o fundamentalismo religioso de um tipo protestante biblicista ou católico romano. Na Declaração das Responsabilidades Humanas não há, propositalmente, nenhuma palavra relativa a questões como controle da natalidade, aborto ou eutanásia, sobre as quais não pode haver consenso entre as religiões ou dentro das Igrejas e religiões. Tampouco (...) a sociedade se manterá coesa pelo pluralismo aleatório, que pretende vender indiferentismo, consumismo e hedonismo como uma visão "pós-moderna" do futuro. Mas no fim a única coisa que manterá a sociedade coesa é um novo consenso social básico sobre valores e critérios compartilhados, que combine auto-realização autônoma com responsabilidade na solidariedade, direitos com obrigações. Assim, não devemos ter medo de uma ética que possa ser apoiada por grupos sociais bastante diferentes entre si. O que necessitamos é de um fundamental sim à moralidade como atitude moral, combinado com um decisivo não ao moralismo, que insiste parcial e firmemente em posições morais particulares (por exemplo, a respeito da sexualidade) (KÜNG, 2001b, p. 111). ${ }^{7}$

De acordo com Hans Küng, a ética mundial comum das religiões, que pode ser adotada por crentes e não-crentes, não é uma nova ideologia ou uma religião mundial unitária, não almeja estabelecer uma cultura mundial uniforme, assim como não tem qualquer pretensão de transformar o ethos específico de cada religião e filosofia em algo supérfluo. Consequentemente, não pode substituir a Torá, o Sermão da Montanha, o Corão, o Bhagavad-Gita, os discursos de Buda ou os Analectos de Confúcio. Um escrito sagrado oferece-nos uma ética máxima, enquanto a ética mundial nos fornece uma ética mínima, que não tem por objetivo responder questões primordiais do homem, como, por exemplo, o sentido da vida e da morte. Além do mais, a ideia de ética mundial não é confessional, ou seja, a religiosidade não é condição prévia da ética mundial (KÜNG, 1999, p. 168; 2001 a, p. 75-76;2002, p. 175 e 178).

Como vimos mais acima, Adela Cortina diferencia os planos da ética pública cívica, que seria a ética dos cidadãos de uma comunidade política concreta, e da ética pública global ou universal, que seria a ética intercultural dos cidadãos do mundo. Para Hans Küng, de forma análoga, pode-se também mencionar dois planos: a ética dos cidadãos, entendida como consenso ético do qual vive o Estado de direito democrático, e a ética global para a política e a economia mundiais da qual estamos tratando (KÜNG, 2001c, p. 57-58).

O núcleo do ethos global, conforme nos ensina Hans Küng, abrange dois princípios éticos fundamentais e quatro diretrizes inafastáveis. Os primeiros são o princípio de humanidade (todo ser humano deve ser tratado humanamente) e a regra de ouro (não faças ao outro o que não queres que façam a ti). As diretrizes inafastáveis, que podem ser encontradas em todas as grandes religiões, são as seguintes: a obrigação de respeitar a vida (não matar); a obrigação de agir com justiça e lisura (não roubar); a obrigação de falar e agir com sinceridade (não mentir); e a obrigação de uma cultura de direitos iguais e de colaboração entre homens e mulheres (não cometer imoralidade sexual) (KÜNG, 1999, p. 197-199; 2001a, p. 60). Nas palavras de Küng, uma declaração para uma ética mundial, que ao invés de ficar limitada ao nível dos direitos ou ao nível político das soluções concretas precisa penetrar em um nível ético mais profundo, não pode ser (a) uma repetição da Declaração dos Direitos Humanos

\footnotetext{
${ }^{7}$ Para a questão formulada por Böckenförde, ver HABERMAS, 2007, p.23.
} 
(a ética, afinal, é mais do que direitos); (b) uma declaração política; (c) um sermão moral casuístico; (d) um tratado filosófico dirigido a intelectuais ou (e) uma proclamação religiosa entusiástica. Em contrapartida, uma declaração para uma ética mundial (a) deve ser capaz de garantir um consenso; (b) deve ser autocrítica; (c) deve estar vinculada à realidade; (d) deve ser compreensível por todos e (e) deve ter um fundamento religioso, apesar de ser destinada também aos não-religiosos (lembremos ainda que, para Küng, uma autonomia baseada numa teonomia não conduz necessariamente a uma heteronomia moral) (KÜNG, 2001a, p. 61-64; 1999, p. 190-192 e 181). Cabe acrescentar que a ética humana básica comum proposta por Hans Küng, vinculando-se a uma tradição que remonta a Cícero, Ambrósio de Milão e Kant, enfatiza os deveres ou responsabilidades. Küng acentua que, no âmbito de uma sociedade de reivindicações, frequentemente indivíduos e grupos insistem em seus direitos contra os outros sem que sejam capazes de reconhecer as próprias responsabilidades. Contudo, direitos humanos e responsabilidades humanas se complementam, sendo falsa a oposição entre direitos libertadores e responsabilidades escravizadoras. Refletir sobre as responsabilidades humanas, portanto, em nada prejudica a realização dos direitos humanos. Além disso, pondera o teólogo suíço, desacreditar a demanda por responsabilidades - tradicional entre os seguidores do confucionismo, do hinduísmo, do budismo e do islamismo - soa como uma atitude arrogante e eurocêntrica (KÜNG, 2001b, p. 112-119; 1999, p. 180).

\section{O DESAFIO DO CONFLITO DE CIVILIZAÇÕES}

Referindo-se ao esforço realizado pelo II Parlamento das Religiões Mundiais no sentido de estabelecer os elementos morais comuns a todas as religiões, Adela Cortina afirma que a melhor maneira de evitar o conflito de civilizações consiste em reforçar os mínimos e ampliá-los. Conforme nos lembra a professora da Universidad de Valencia, Samuel Huntington pôs sobre a mesa "a provocativa sugestão de que, nos nossos dias, a divisão mais profunda da humanidade é uma divisão entre civilizações, cada uma delas tendo nas suas raízes uma religião" (CORTINA, 2003a, p. 277; 1998, p. 119-120). De acordo com Juan José Tamayo, Huntington nos apresenta uma tese binária: primeiramente, afirma que, no mundo pós-Guerra Fria, as pautas de coesão, desintegração e conflito estão sendo configuradas pelas culturas e identidades culturais, de modo que a fidelidade cultural é o que há de mais significativo para as pessoas; em segundo lugar, afirma que as guerras do século XXI não vão contrapor as classes sociais, as ideologias, os sistemas políticos, as nações ou os modelos econômicos, mas sim as civilizações (TAMAYO, 2009, p. 133). Segundo Tamayo, no entanto, o choque de civilizações não deve ser visto como a descrição de um fato ou como uma lei que rege a história, traduzindo, ao invés disso, uma construção ideológica do Império com o objetivo de manter sua influência sobre o resto do mundo (TAMAYO, 2009, p. 135). Hans Küng, em que pesem as várias objeções que direciona contra Huntington (como veremos mais à frente) reconhece que o professor de Harvard tem o grande mérito de levar a sério a dimensão cultural-religiosa da 
política mundial. Para o autor do brilhante e desafiador livro intitulado The Clash of Civilizations and the Remaking of World Order (publicado no ano de 1996, agora sem o ponto de interrogação do artigo The Clash of Civilizations? ,publicado no periódico Foreign Affairs, no verão de 1993), a cultura conta e as identidades culturais (étnicas, nacionais, religiosas e civilizacionais), como já foi dito, são o que existe de mais relevante para a maioria das pessoas (HUNTINGTON, 1997, p. 20 e 392).A partir de sua proposição central (no sentido de que, no mundo pós-Guerra Fria, a cultura e as identidades culturais determinam os padrões de coesão, desintegração e conflito), Huntington estabelece os seguintes desdobramentos: (a) pela primeira vez na história, a política mundial revela-se, ao mesmo tempo, multipolar e multicivilizacional, de modo que podemos falar em um mundo de civilizações; (b) produz-se uma alteração no equilíbrio de poder entre as civilizações, com o declínio da influência do Ocidente e a concomitante afirmação do valor das civilizações não-ocidentais; (c) está surgindo uma ordem mundial baseada na identidade civilizacional; (d) em decorrência de suas pretensões universalistas, o Ocidente, cada vez mais, entra em conflito com outras civilizações; e (e) a sobrevivência do Ocidente exige que os norte-americanos reafirmem sua identidade ocidental e que os ocidentais aceitem o fato de que sua civilização é singular ao invés de universal (HUNTINGTON, 1997, p. 18-19). O mundo pós-Guerra Fria, escreve Samuel Huntington, é um mundo de sete ou oito civilizações principais, onde a cultura unifica e divide. O paradigma da Guerra Fria (com uma política mundial bipolar e o mundo dividido em três blocos), como se vê, foi substituído pelo paradigma civilizacional. De acordo com este último, assinala Huntington, (a) as forças de integração no mundo estão gerando forças contrárias de afirmação cultural e civilizacional; (b) o mundo está dividido entre a civilização ocidental e várias civilizaçoes não-ocidentais que muito diferem entre si; (c) as alianças e os conflitos entre Estados-nações estão sendo cada vez mais determinados por fatores culturais e civilizacionais; e, por fim, (d) embora o mundo seja anárquico, repleto de conflitos tribais e de nacionalidade, os conflitos entre Estados ou grupos de diferentes civilizações são os que representam maior ameaça para a estabilidade (HUNTINGTON, 1997, p. 20, 28, 29 e 39).

Samuel Huntington enumera algumas características das civilizações. Em primeiro lugar, uma civilização é definida por elementos objetivos comuns, como língua, raça, história, costumes, instituições e religião, sendo este último, em geral, o mais importante. Em segundo lugar, civilização e raça não se confundem: assim como povos de uma mesma raça podem estar divididos pela civilização, povos de raças diferentes podem estar unidos por intermédio da civilização. Em terceiro lugar, a civilização é a entidade cultural mais ampla; é uma totalidade que abrange sem ser abrangida. A civilização é o nível mais amplo de vínculo com o qual o indivíduo se identifica de forma intensa. Em quarto lugar, as civilizações são as mais duradouras dentre todas as associações humanas. Porém, embora durem muito tempo, elas não são imortais. Em quinto lugar, as civilizações são entidades culturais ao invés de políticas. Cada civilização pode conter uma ou mais unidades políticas (cidades-Estados, impérios, federações, confederações, Estados-nações, Estados multinacionais), sendo mais frequente a pluralidade de vol.09, no. 04, Rio de Janeiro, 2016. pp. 2248-2262 2258 
unidades políticas. Como são entidades culturais, não cabe às civilizações, como tal, manter a ordem, estabelecer a justiça, arrecadar impostos, travar guerras ou negociar tratados (HUNTINGTON, 1997, p. 46-50). Tendo em mente que a religião é um traço essencial para se definir uma civilização (as grandes religiões alicerçam as civilizações), Samuel Huntington nos ensina que as principais civilizações contemporâneas são as seguintes: a sínica, a japonesa, a hindu, a islâmica, a ortodoxa, a ocidental, a latino-americana e, possivelmente, a africana (HUNTINGTON, 1997, p. 50-54).

Hans Küng levanta algumas objeções contra a hipótese formulada por Huntington no sentido de que as guerras, no mundo atual, haverão de ser, principalmente, guerras entre civilizações, marcadas pela presença religiosa. Em primeiro lugar, fomenta-se a mentalidade de blocos, visto que as sete ou oito principais civilizações são visualizadas como grandezas monolíticas rigidamente delimitadas, como se elas não coincidissem em parte e não se interpenetrassem umas com as outras. Em segundo lugar, apresenta-se um sistema de referências simplificado e falso, no qual algumas civilizações, como a islâmica, a hinduísta, a confucionista e a ortodoxa seriam determinadas a partir da religião, ao contrário do que ocorreria com outras, como a ocidental e a japonesa. Em terceiro lugar, contrastes são enfatizados e pontos em comum são ignorados. No âmbito da cristandade, por exemplo, não só a civilização oriental-ortodoxa é diferenciada da civilização ocidental, como também a civilização ocidental norte-americana é diferenciada da civilização latino-americana. Küng acrescenta ainda que não compartilha do fatalismo de Huntington. O teólogo suíço acredita que, se o choque global de civilizações é um modelo de terror útil para muitos estrategistas militares, o futuro da humanidade está na busca de uma paz global entre as religiões, capaz de fundamentar e impulsionar a paz global entre as nações. Dito de outra forma, o modelo para o futuro não é a luta, mas sim a cooperação entre as culturas (KÜNG, 1999, p. 206-212).

Hans Küng não deixa de assinalar, contudo, que Samuel Phillips Huntington, nas cinco últimas páginas de O Choque de Civilizações e a Recomposição da Ordem Mundial, admite que as grandes religiões compartilham alguns valores, o que, pensa Küng, relativizaria o livro inteiro (KÜNG, 1999, p. 211-212).

De acordo com Samuel Huntington, a história das civilizações nos ensina que, embora muitas coisas sejam prováveis, nada é inexorável. Consequentemente, uma guerra de grandes proporções envolvendo o Ocidente e Estados-núcleos de outras civilizações pode vir a ocorrer, mas não é inevitável (HUNTINGTON, 1997, p. 384 e 386). Neste sentido, Huntington enumera três regras para a paz em um mundo multipolar e multicivilizacional. A regra de abstenção estabelece que os Estados-núcleos (ou Estados-líderes) de uma civilização não devem intervir em conflitos ocorridos no interior de outras civilizações. A regra de mediação conjunta estabelece que os Estados-núcleos devem negociar entre si a fim de conter ou interromper guerras de linha de fratura envolvendo Estados ou grupos de suas próprias civilizações. Cabe esclarecer que a guerra de linha de fratura, sendo uma guerra local entre grupos locais com ligações culturais mais amplas, fortalece as identidades civilizacionais dos contendores; daí sua percepção como um conflito de civilizações. Por fim, a regra dos aspectos vol.09, n. 04, Rio de Janeiro, 2016. pp. 2248-2262 2259 
em comum estabelece que os povos de todas as civilizações devem buscar e, se possível, expandir os valores que compartilham com os povos de outras civilizações (HUNTINGTON, 1997, p. 340-345 e 403-408).

Samuel Huntington refuta o multiculturalismo interno (que ameaça os Estados Unidos e o Ocidente) e o universalismo externo (que ameaça o Ocidente e o mundo), pois ambos, segundo entende, negam a singularidade da cultura ocidental. Os multiculturalistas norte-americanos atacam os componentes cultural e político da identidade norte-americana, que são, respectivamente, o legado da civilização ocidental e o credo norte-americano (liberdade, democracia, individualismo, igualdade perante a lei, constitucionalismo e propriedade privada). Citando James Kurth (The Real Clash), Huntington assevera que o conflito envolvendo, de um lado, os multiculturalistas e, de outro, os defensores da civilização ocidental e do credo norte-americano, é o verdadeiro conflito no interior do segmento norte-americano da civilização ocidental. Por sua vez, escreve Samuel Huntington, a crença ocidental (e norte-americana, especialmente) na universalidade da cultura ocidental é contestada pela diversidade cultural e civilizacional. Tal crença pode ser exprimida tanto de maneira descritiva (em todas as sociedades as pessoas, efetivamente, querem adotar as instituições e os valores ocidentais), como de maneira normativa (no mundo inteiro, as pessoas deveriam abraçar as instituições e os valores ocidentais, pois representam a forma mais civilizada de pensamento humano). Seja como for, a crença universalista ocidental, prossegue Huntington, é falsa, imoral e perigosa. Falsa porque a diversidade cultural está muito longe de configurar uma mera curiosidade histórica que pudesse ser superada pelo aparecimento de uma cultura mundial comum. Imoral porque a consequência lógica e necessária do universalismo é o imperialismo. Perigosa porque poderia levar a uma guerra intercivilizacional entre Estados-núcleos, inclusive, com a derrota do Ocidente. Em síntese, o valor da civilização ocidental decorre do fato de ser única, e não de sua pretensa universalidade (HUNTINGTON, 1997, p. 388-396 e 405; TAMAYO, 2009, p. 134). A par de sua crítica ao multiculturalismo e ao universalismo, Samuel Huntington, como mencionado, admite que as principais religiōes do mundo compartilham alguns valores centrais, de forma que em um nível elementar de moralidade "delgada" existem aspectos em comum entre, por exemplo, o Ocidente e a Ásia (HUNTINGTON, 1997, p. 408). Apoiado em Michael Walzer, Samuel Huntington esclarece sua posição:

As culturas são relativas, a moralidade é absoluta. Como sustentou Michael Walzer, as culturas são "espessas", elas prescrevem instituições e padrões de comportamento para guiar os seres humanos pelos caminhos que são os corretos dentro de uma determinada sociedade. Entretanto, acima, além e brotando dessa moralidade maximalista existe uma "delgada" moralidade minimalista, que encarna "aspectos reiterados das moralidades espessas ou maximalistas". Conceitos minimalistas morais de verdade e justiça são encontrados em todas as moralidades espessas e não podem ser divorciados delas. Há também "injunções negativas" de moralidade minimalista, "mais provavelmente regras contra assassinato, fraude, tortura, opressão e tirania". O que as pessoas têm em comum é "mais o sentido de um inimigo [ou mal] comum do que uma dedicação a uma cultura comum". A sociedade humana é "universal porque ela é humana, particular porque é uma sociedade". Às vezes caminhamos com os outros, na maioria das vezes caminhamos 
sozinhos. (...) Em vez de promover os aspectos supostamente universais de uma civilização, os requisitos para a coexistência cultural exigem uma busca do que é comum à maioria das civilizações. Num mundo multicivilizacional, o caminho construtivo reside em renunciar ao universalismo, aceitar a diversidade e buscar os aspectos em comum (HUNTINGTON, 1997, p. 405).

\section{CONCLUSÃO}

Diante de todo o exposto, concluímos que a ética mundial das religiões, na qualidade de uma ética mínima, nos permite enfrentar o desafio do conflito de civilizações. Sendo assim, no limiar do terceiro milênio, como salienta Hans Küng (KÜNG, 1999, p. 203), se, por um lado, as religiões aparecem como grandes perturbadoras da paz no mundo, por outro, podem se converter nas grandes parteiras do ethos global.

\section{THE GLOBAL ETHICS OF RELIGIONS AND THE CHALLENGE OF THE CLASH OF CIVILIZATIONS}

\section{Abstract}

The article discusses the global ethics of religions and the challenge of the conflict of civilizations. Firstly we insert the project of a world common ethics of religions developed by Hans Küng in the field of minimal ethics. Secondly, we synthesize the paradigm of the clash of civilizations, presented by Samuel Huntington in his book The Clash of Civilizations and The Remaking of World Order.

Keywords: Hans Küng; Samuel Huntington; Adela Cortina; global ethics; clash of civilizations.

\section{REFERÊNCIAS BIBLIOGRÁFICAS}

APEL, Karl-Otto. Transformação da Filosofia II, São Paulo, Loyola, 2000.

AUDARD, Catherine. "John Rawls e o conceito do político", in Justiça e Democracia, Catherine Audard (org.), São Paulo, Martins Fontes, 2000.

CIOTOLA, Marcello. "Michael Walzer e as duas formas da argumentação moral", in Juris Poiesis, ano 16, n 16, 2013.

"Ética cívica e fundamentação das leis no Estado laico", in La Laicidad, Antonio Pele, Oscar Celador Angón e Hilda Garrido Suárez (orgs.), Madrid, Dykinson, 2014.

CORTINA, Adela. Hasta un Pueblo de Demonios, Madrid, Taurus, 1998.

Ética Aplicada y Democracia Radical, $3{ }^{a}$ ed., Madrid, Tecnos, 2001 a.

Ética Mínima, 7 a ed., Madrid, Tecnos, 2001 b.

"Ética transnacional e cidade cosmopolita", in Direito e Legitimidade, Jean-Christophe Merle e Luiz Moreira (orgs.), São Paulo, Landy, 2003a. 
"La ética empresarial en el contexto de una ética cívica", in Ética de la Empresa: Claves para una Nueva Cultura Empresarial, Adela Cortina (org.), 6 a ed., Madrid, Trotta, 2003b.

Alianza y Contrato, $2^{a}$ ed., Madrid, Trotta, 2005.

Justicia Cordial, Madrid, Trotta, 2010.

CORTINA, Adela e MARTÍNEZ, Emilio. Ética, São Paulo, Loyola, 2005.

GONZÁLEZ-CARVAJAL SANTABÁRBARA, Luis. Los Cristianos en un Estado Laico, Madrid, PPC, 2008.

HABERMAS, Jürgen. "Fundamentos pré-políticos do Estado de direito democrático?", in HABERMAS, Jürgen e RATZINGER, Joseph. Dialética da Secularização (Florian Schüller, org.), 3a ed., Aparecida, Idéias e Letras, 2007.

HUNTINGTON, Samuel. O Choque de Civilizações e a Recomposição da Ordem Mundial, Rio de Janeiro, Objetiva, 1997.

KÜNG, Hans. Uma Ética Global para a Política e a Economia Mundiais, Petrópolis, Vozes, 1999. "História, importância e método da Declaração para uma Ética Global", in KÜNG, Hans e SCHMIDT,

Helmut. Uma Ética Mundial e Responsabilidades Globais, São Paulo, Loyola, 2001 a.

"Não tenha medo de princípios morais!", in KÜNG, Hans e SCHMIDT, Helmut. Uma Ética Mundial e

Responsabilidades Globais, São Paulo, Loyola, 2001b.

Projeto de Ética Mundial, 3 a ed., São Paulo, Paulinas, 2001c.

¿Por qué una ética mundial? Religión y ética en tiempos de globalización. Conversaciones con Jürgen

Hoeren, Barcelona, Herder, 2002.

KÜNG, Hans. Humanidad Vivida. Memorias, Madrid, Trotta, 2014.

LUDMER, Juliana. O Projeto de Ética Mundial de Hans Küng, Rio de Janeiro, Multifoco, 2016.

RAWLS, John. Collected Papers, Samuel Freeman (org.), Cambridge, Harvard University Press, 1999.

"A teoria da justiça como eqüidade: uma teoria política, e não metafísica", in Justiça e Democracia, Catherine Audard (org.), São Paulo, Martins Fontes, 2000a.

O Liberalismo Político, São Paulo, Ática, 2000b.

Justiça como Eqüidade: uma Reformulação, Erin Kelly (org.), São Paulo, Martins Fontes, 2003.

História da Filosofia Moral, Barbara Herman (org.), São Paulo, Martins Fontes, 2005.

TAMAYO, Juan José. Fundamentalismos y Diálogo entre Religiones, $2^{a}$ ed., Madrid, Trotta, 2009.

VIDAL, Marciano. Nova Moral Fundamental, São Paulo, Paulinas, 2003.

Trabalho enviado em 20 de setembro de 2016.

Aceito em 01 de novembro de 2016. 